\title{
Pengaruh Perbedaan Salinitas Terhadap Viabilitas Bakteri Pseudomonas spp.
}

\author{
${ }^{1}$ Apri Arisandi, ${ }^{2}$ Maulinna Kusumo Wardhani, ${ }^{3}$ Kaswan Badami, ${ }^{4}$ Anisa Sopiyanti \\ 1,2,4Program Studi Ilmu Kelautan, Universitas Trunojoyo Madura \\ ${ }^{3}$ Program Studi Agroteknologi, Universitas Trunojoyo Madura \\ 1apri_unijoyo@yahoo.com
}

\begin{abstract}
ABSTRAK
Kondisi perairan laut yang fluktuatif dan cenderung ekstrim menyebabkan rumput laut mudah terserang penyakit ice-ice. Munculnya bercak putih pada thallus rumput laut Eucheuma cottonii yang terinfeksi penyakit ice-ice diduga disebabkan oleh bakteri patogen yaitu Pseudomonas spp. Tujuan yang ingin dicapai dalam pelaksanaan penelitian ini adalah untuk mengetahui pengaruh perbedaan salinitas terhadap viabilitas bakteri Pseudomonas spp dan untuk mengetahui pada salinitas berapakah bakteri Pseudomonas spp tidak dapat tumbuh. Bakteri diidentifikasi melalui uji biokimia, dan viabilitas diamati dengan menanam bakteri pada media TSA plate dengan salinitas 30, 32, dan 34 ppt dengan 3 kali pengulangan, dan untuk uji konfirmasi bakteri di tanam pada media TSA miring dengan kadar salinitas 0, 20, 40, 60, 80, dan 100 ppt. Hasil yang diperoleh menunjukan bakteri tumbuh dengan normal pada hampir semua media uji kecuali pada media 100 ppt, hal ini menunjukan bahwa bakteri Pseudomonas spp merupakan bakteri yang bersifat halofilik atau dapat tumbuh baik pada kadar salinitas yang tinggi.
\end{abstract}

Kata Kunci: Eucheuma cottonii, ice-ice, Pseudomonosa spp, Viabilitas.

The Influence of Salinity Difference to Viability of Pseudomonas spp. Bacteria

\section{ABSTRACT}

The conditions of marine waters that fluctuate and tend to extremes can cause seaweed susceptible to ice-ice disease. The appearance of white patches on infected Eucheuma cottonii seaweed thallus is estimated as ice-ice disease which is caused by pathogenic bacteria of Pseudomonas spp The objectives of this research is to determine the effect of salinity difference to viability of bacteria Pseudomonas spp and to know on what salinity is the bacterium Pseudomonas spp that can't grow. Bacteria were identified by biochemical tests. Viability was observed by planting bacteria on TSA plate medium with salinity 30 ppt, 32 ppt, and 34 ppt with 3 repetitions, and for bacterial confirmation test in planting on TSA tilting with salinity 0 ppt, 20 ppt, 40 ppt, 60 ppt, 80 ppt, And 100 ppt. The results showed that bacteria grew normally in almost all test media except in 100 ppt media, this showed that Pseudomonas spp bacteria were halophilic bacteria or could grow well at high salinity levels.

Keywords: Eucheuma cottonii, ice-ice, Pseudomonosa spp, Viability. 


\section{PENDAHULUAN}

Rumput laut Eucheuma cottonii dapat tumbuh dengan baik pada musim kemarau, sebaliknya pada musim hujan pertumbuhannya dapat melambat (Arisandi 2013). Pertumbuhan Eucheuma cottonii yang lambat di musim hujan disebabkan oleh kisaran salinitas dan suhu yang fluktuatif (Msuya dan Salum 2007). Kebanyakan makroalga atau rumput laut mempunyai toleransi yang rendah terhadap perubahan salinitas (Khasanah 2013). Begitu pula dengan spesies Eucheuma cottonii merupakan jenis rumput laut yang bersifat stenohaline atau organisme yang hanya dapat beradaptasi dengan sedikit perubahan salinitas. Salinitas dapat berpengaruh terhadap proses osmoregulasi pada tumbuhan rumput laut (Aslan 1991). Salinitas yang tinggi dapat menghambat pertumbuhan rumput laut.

Pada rumput laut yang terserang penyakit ice-ice ditemukan pula adanya bakteri. Darmayanti et al. (2001) menyebutkan bahwa hampir seluruh contoh rumput laut yang diambil dari budidaya di pantai Takalar Sulawesi Selatan ditemukan bakteri jenis Vibrio spp. Aeromonas sp. dan Pseudomonas spp. Perubahan salinitas atau kadar garam dapat mempengaruhi kadar air dalam tumbuh mikroba (Agustono et al. 2012). Salinitas berhubungan erat dengan tekanan osmotik yang berpengaruh terhadap pertumbuhan bakteri.

\section{METODE PENELITIAN}

Pengambilan sampel dilaksanakan pada tanggal 06 Mei 2017 pada saat musim hujan di Kecamatan Bluto Kabupaten Sumenep. Isolasi bakteri dan pengamatan pertumbuhan bakteri Pseudomonas spp dari sampel dilakukan pada tanggal 8-14 Mei 2017 dilaksanakan di Laboratorium Uji Balai Karantina Ikan Pengendalian Mutu Dan Keamanan

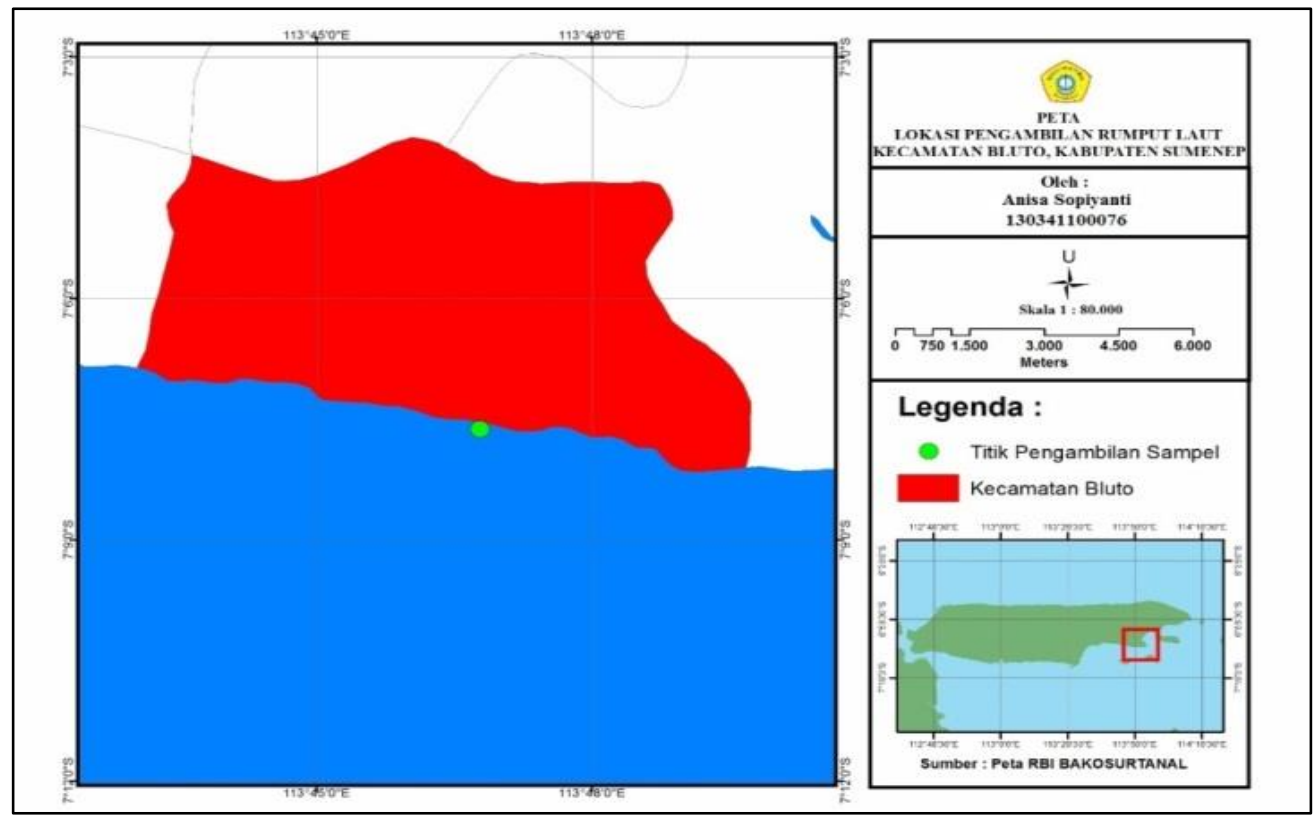

Gambar 1. Peta Lokasi Penelitian 
Hasil Perikanan Kelas I Surabaya II. (Gambar 1).

Sampel rumput laut eucheuma cottoni yang digunakan merupakan rumput laut yang memiliki gejala klinis terserang penyakit iceice yaitu munculnya bercak putih pada rumput laut (sebanyak 25gr) yang diambil dari lokasi penelitian. Selanjutnya sampel rumput laut yang terinfeksi bakteri akan dilakukan isolasi dan identifikasi bakteri. Setelah dipastikan bahwa bakteri hasil isolasi merupakan bakteri Pseudomonas spp maka dilanjutkan dengan melakukan penanaman bakteri pada beberapa salinitas yang berbeda yaitu 30 ppt, 32 ppt, dan 34 ppt dengan 3 kali pengulangan. Dilanjutkan dengan penanaman pada salinitas 0 ppt, 2 ppt, 4 ppt, 6 ppt, 8 ppt, dan 10 ppt yang dilakukan unuk uji konfirmasi.

\section{HASIL DAN PEMBAHASAN Identifikasi Bakteri}

Identifikasi bakteri dilakukan dengan menggunakan acuan buku ientifikasi Bergey's Manual Determinative Bacteriology Ninth Edition (Holt et. al 1984).

Tabel 1 Hasil Pengamatan Morfologi

\begin{tabular}{lll}
\hline NO & JENIS PENGUJIAN & HASIL PEMERIKSAAN \\
\hline 1. & Warna Koloni & Krem \\
2. & Tepi Koloni & Rata \\
3. & Elevasi & Cembung \\
4. & Struktur dalam & Lembut \\
\hline
\end{tabular}

Tabel 2 Hasil Uji Presumtif

\begin{tabular}{llcc}
\hline NO & JENIS PENGUJIAN & HASIL PEMERIKSAAN & Saraswati (2016) \\
\hline 1 & Uji Gram & - & + \\
2 & Uji Katalase & + & + \\
3 & Uji Oksidase & + & + \\
\hline
\end{tabular}

Tabel 3 Hasil Pengujian Biokimia

\begin{tabular}{|c|c|c|c|}
\hline NO & JENIS PENGUJIAN & HASIL PEMERIKSAAN & Saraswati (2016) \\
\hline 1. & Uji Gula-gula & - & - \\
\hline 2. & TSI Agar & $\mathrm{K} / \mathrm{K}$ & $\mathrm{K} / \mathrm{K}$ \\
\hline 3. & Gas/H2S & $-/-$ & $-/-$ \\
\hline 4. & $\mathrm{O} / \mathrm{F}$ & $\mathrm{O}$ & $\mathrm{O}$ \\
\hline 5. & Nitrate Reduction & + & + \\
\hline 6. & Gelatin & - & - \\
\hline 7. & MIO & $+/ /+$ & $+/-/+$ \\
\hline 8. & Simmons Citrate & + & + \\
\hline 9. & Malonate & + & + \\
\hline 10. & Chirstensen's Urease & + & - \\
\hline 11. & MR/VP & $-/-$ & $-/-$ \\
\hline
\end{tabular}


Berdasarkan hasil identifikasi yang telah dilaksanakan, ditemukan 7 genus bakteri yang terdapat pada Thallus rumput laut yang memiliki gejala klinis terserang penyakit iceice diantaranya yaitu: Chromobacterium sp, Flavobacterium sp, Vibrio spp, Yersinia sp, Acinnobacter sp, Hafnia sp, dan Pseudomonas spp. Pengamatan morfologi bakteri dilakukan untuk mengamati ciri-ciri koloni bakteri. Beberapa kelompok mikroorganisme menunjukan ciri-ciri koloni yang berbeda, baik dilihat dari betuknya, elevasi, struktur dalam bakteri, maupun bentuk tepi koloni. Hasil pengujian dapat dilihat pada Tabel 1.

Uji presumtif bakteri dilakukan bertujuan untuk memudahkan dalam tahap identifikasi sampai tingkat genus, uji yang dilakukan meliputi uji gram, uji katalase, uji oksidase, hasil pengujian dapat dilihat pada Tabel 2 .

Uji biokimia dilakukan untuk mengetahui spesies dari bakteri yang ditemukan dan telah di lakukan uji Presumtif dan pengamatan morfologi untuk mengetahui genusnya, hasil pengujian dapat dilihat pada Tabel 3 .

\section{Viabilitas Bakteri Pseudomonas spp pada Perlakuan Salinitas Berbeda}

Bakteri yang dikultur dipastikan merupakan bakteri Pseudomonas spp maka dilanjutkan dengan kultur bakteri pada media TSA yang telah dimodifikasi salinitasnya hingga mencapai $30 \mathrm{ppt}$, 32 ppt, dan 34 ppt pada wadah cawan petri (Gambar 2) Selanjutnya diinkubasi selama 2x24 jam untuk diamati viabilitasnya. Rentan salinitas 30-34 ppt digunakan sebagai acuan untuk memodifikasi

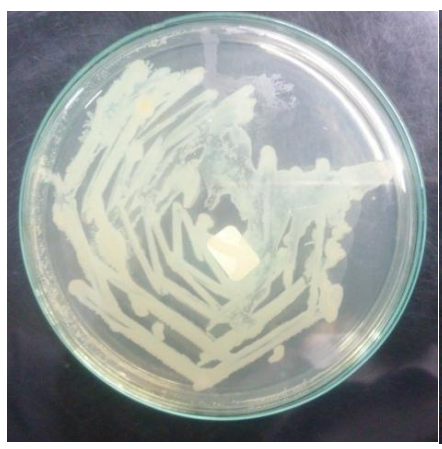

(a)

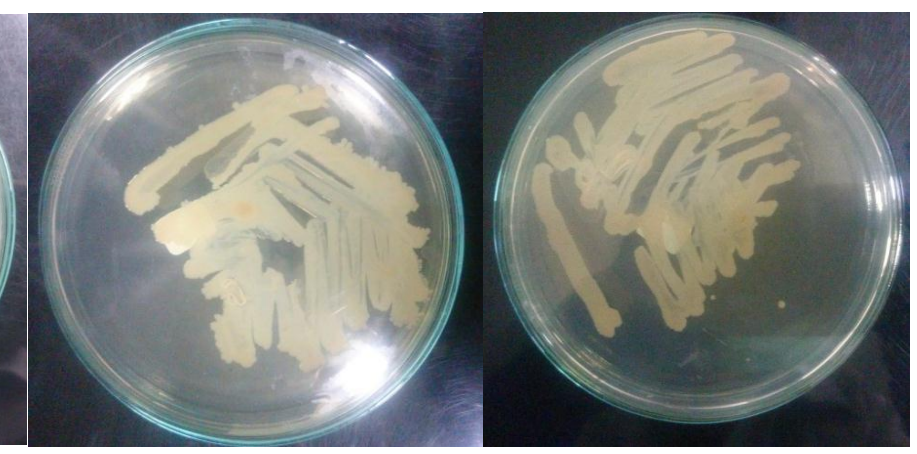

(b) (c)

Gambar 2. Media TSA dengan salinitas (a) 30 ppt (b) 32 ppt (c) 34 ppt

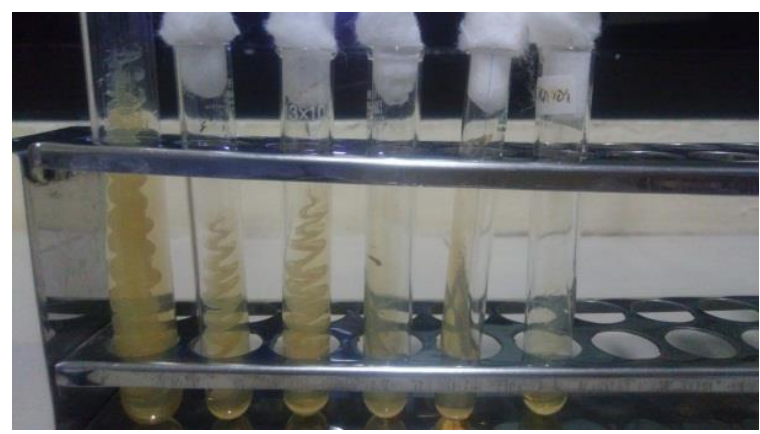

Gambar 3. Pertumbuhan bakteri Pseudomonas spp pada media TSA miring 
media ini berdasarkan pada salinitas normal bagi lingkungan hidup rumput laut Kappaphycus alvarezii yang dapat tumbuh dengan baik pada perairan dengan salinitas $28-34 \%$ o (Santoso 2008).

Pengamatan yang dilakukan pada salinitas 30-34 ppt yang talah diinkubasi selama \pm 48 jam dengan menggunakan 3 kali pengulangan pada setiap salinitas menunjukan hasil bahwa bakteri tumbuh dengan normal pada keseluruhan media yang dibuat. Tidak terdapat tanda kontaminasi pada media pengamatan. Sehingga dilakukan uji konfirmasi. Uji konfirmasi dilakukan dengan menggunakan media TSA miring pada tabung reaksi. Hal ini dilakukan untuk menurunkan resiko kontaminasi dari pada penanaman bakteri pada plate atau cawan petri. Sehingga pengujian dilanjutkan dengan rentan salinitas yang lebih tinggi untuk memperoleh batas atas dan bawah pertumbuhan bakteri Pseudomonas spp. Penanaman dilakukan yaitu pada salinitas 0,20 , 40, 60, 80 dan 100 ppt (Gambar 3).

Penggunaan media miring ini bertujuan untuk hanya mengamati pertumbuhan dari bakteri Pseudomonas spp. Hasil yang diperoleh setelah inkubasi selama 48 jam pada suhu $\pm 35^{\circ} \mathrm{C}$ adalah pada salinitas 0 ppt bakteri tumbuh melimpah dan hampir memenuhi media. Pada salinitas 20-60 ppt bakteri tumbuh dengan normal pada media. Salinitas 80 ppt pertumbuhan bakteri mengalami penurunan atau hanya sedikit bakteri yang hidup. Pada salinitas 100 ppt bakteri tidak dapat tumbuh sama sekali (Tabel 4).

Bakteri dikategorikan
tumbuh normal 100\% apabila
pertumbuhan bakteri sesuai dengan
goresan jarum ose, jika pertumbuhan
tidak memenuhi goresan jarum ose
maka dapat dikatakan pertumbuhan
bakteri mengalami penurunan.
Apabila bakteri tumbuh diluar dari
goresan jarum ose maka dapat
dikatakan bakteri mengalami
kontaminasi. Berdasarkan gambar
dan tabel diatas dapat dilihat bahwa
bakteri Pseudomonas spp tetap
tumbuh normal pada rentan salinitas
$0 \quad$ sampai 20 ppt. Namun
pertumbuhan mulai mengalami
penurunan pada salinitas 40 ppt, 60
ppt dan 80 ppt, dan sama sekali tidak
tumbuh pada salinitas 100 ppt. Hal ini
dipengaruhi oleh sifat bakteri
Pseudomonas spp yang merupakan
bakteri halofilik atau merupakan
bakteri yang dapat tetap tumbuh
pada kadar salinitas yang tinggi.
Suriawiria (1996) menyatakan bahwa

Tabel 4 Hasil Penanaman Bakteri pada Media TSA

\begin{tabular}{ccccc}
\hline No & Jenis Media & Salinitas (Ppt) & Pertumbuhan & Keterangan \\
\hline 1. & TSA Plate & 30 & Tumbuh & Normal $100 \%$ \\
2. & TSA Plate & 32 & Tumbuh & Normal $100 \%$ \\
3. & TSA Plate & 34 & Tumbuh & Normal $100 \%$ \\
4. & Tsa Miring & 0 & Tumbuh & Normal $100 \%$ \\
5. & Tsa Miring & 20 & Tumbuh & Normal $100 \%$ \\
6. & Tsa Miring & 40 & Tumbuh & Normal $90 \%$ \\
7. & Tsa Miring & 60 & Tumbuh & Normal $50 \%$ \\
8. & Tsa Miring & 80 & Tumbuh & Normal $10 \%$ \\
9. & Tsa Miring & 100 & Tumbuh & Tidak tumbuh \\
\hline
\end{tabular}


terdapat beberapa mikroorganisme yang dapat menyesuaikan diri dan dapat tetap tumbuh pada kadar garam atau kadar gula yang tinggi. Bahkan beberapa mikroorganisme dapat tahan di dalam substrat dengan kadar garam sampai 30\%.

Bakteri halofilik merupakan bakteri yang pertumbuhannya tergantung pada kadar $\mathrm{NaCl}$ dan mampu tetap tumbuh pada salinitas tinggi (Pelczar dan chan 1998). Kadar garam habitat bakteri halofilik berkisar antara 2\% hingga 30\% (Ventosa 1995). Bakteri halofilik membutuhkan konsentrasi $\mathrm{NaCl}$ minimal tertentu untuk pertumbuhannya. Kebutuhan garam untuk pertumbuhan optimum bervariasi yaitu 20-50 ppt untuk bakteri halofilik ringan, 50-200 ppt untuk bakteri halofilik sedang, 200300 ppt untuk bakteri halofilik ekstrem. Namun pada penelitian ini bakteri Pseudomonas spp tetap tumbuh pada media dengan kadar salinitas 0 ppt hal ini sesuai dengan pendapat Holt et al. (1994) yang menyatakan bahwa Pseudomonas merupakan bakteri yang tergolong kedalam halofilik dengan kemampuan tumbuhnya di medium yang memiliki kadar $\mathrm{NaCl} 0 \mathrm{ppt}$ hingga $300 \mathrm{ppt}$.

\section{DAFTAR PUSTAKA}

Agustono, Hari, S. dan Muhajir. 2012. Strategi Bakteri Probiotik untuk Menekan Pertumbuhan Bakteri Patogen didalam Pengenceran Kerapu Chromileptes altivelis dengan Memproduksi Beberapa Bakterial Substansi. Jurnal IImiah Perikanan dan Kelautan. Fakultas Perikanan dan Kelautan Universitas Airlangga. Surabaya. Vol. 4 No. 2 : 199-205.
Pada penelitian ini bakteri Pseudomonas spp dapat tumbuh normal pada kadar garam 0-40 ppt. Pada konsentrasi garam 40-80 ppt pertumbuhan Pseudomonas spp mulai terganggu ditandai dengan pertumbuhan nya yang menurun atau sedikit. Pada konsentrasi 80-100 ppt bakteri Pseudomonas spp tidak dapat tumbuh sama sekali, dapat di aertikan bahwa pada konsetrasi 80100 ppt merupakan batas atas bagi pertumbuhan bakteri Pseudomonas spp.

\section{SIMPULAN}

\begin{tabular}{lcr}
\multicolumn{2}{c}{ Berdasarkan } & penelitian \\
pengaruh & perbedaan & salinitas \\
terhadap & viabilitas & bakter
\end{tabular} Pseudomonas spp yang telah dilakukan maka dapat diambil kesimpulan yaitu, Perlakuan salinitas yang berbeda mempengaruhi pertumbuhan bakteri Pseudomonas spp. Bakteri ini memiliki toleransi tinggi terhadap salinitas yaitu $0 \mathrm{ppt}$ hingga 40 ppt, pertumbuhan menurun pada salinitas 40 hingga 80 ppt hingga pertumbuhan bakteri terhenti pada salinitas 80 hingga 100 ppt.

Aslan, L.M. 1991. Budidaya Rumput Laut. Penerbit Kanisius, Yogyakarta

Arisandi, A., Akhmad, F., Eva, A, W., Siti, R. 2013. Dampak Infeksi Ice-ice dan Epifit terhadap Pertumbuhan Eucheuma cottonii. IImu Kelautan 18 (1) $1-6$.

Darmayanti, Y., A. Hatmanti, N. Farida dan Surahman 2001. Studi hama dan penyakit. Laporan akhir Penelitian Pengembangan Bibit Unggul Rumput Laut, Pengelolaan Kualitas Air serta Hama dan Penyakitnya. Proyek 
Penelitian, Pengembangan dan Pemanfaatan Sumberdaya Laut Dalam. Pusat Penelitian Oseanografi-LIPI Jakarta. $7 \mathrm{Hal}$.

Holt, J.G., Krieg, N.R., Sneath, H.A., Stanley, J.T. dan William, S.T. 1994. Bergey's Manual of Determinative Bacteriology 9th Edition. Williams and Wilkins, Baltimor.

Khasanah, U. 2013. Analisis Kesesuaian Perairan Untuk Lokasi Budidaya Rumput Laut Eucheuma Cottonii Di Perairan Kecamatan Sajoanging Kabupaten Wajo. Skripsi tidak diterbitkan. Makasar: Universitas Hasanuddin.

Msuya, F.E., \& D. Salum. 2007. The Effect of Cultivation, Duration, Seasonality and Nutrient Conentration of The Growth Rate and Biomasa Yield Of The Seaweeds Kappaphycusalvarezii and Eucheuma denticulatum in
Zanzibar, Tanzania. MARG-I Final Report submitted to The Western Indian Ocean Marine Sciences Association (WIOMSA), $23 \mathrm{pp}$.

Pelczar, Michael dan E.C.S.Chan. 1986. Dasar-Dasar Mikrobiologi. Cetakan I. Jakarta: UI-Press. Hal. 101.

Santoso, L., Yudha, T, N. 2008. Pengendalian Penyakit Ice-Ice Untuk Meningkatkan Produksi Rumput Laut Indonesia. Jurnal Saintek Perikanan Vol. 3 No. 2, : $37-43$

Suriawiria, U. 1996. Mikrobilologi Air dan Dasar-Dasar Pengolahan Air Buangan Secara Biologis, Penerbit Alumni, Bandung.

Ventosa, A., Nieto, J.J. dan Oren, A. 1998. Biology of Moderately Halophilic Aerobic Bacteria. Microbiol. Mol Biol. Rev 62: 504544 